\title{
Ethnochemistry and Ethnomedicine of Ancient Papua New Guineans and Their Use in Motivating Students in Secondary Schools and Universities in PNG
}

\author{
Basil Marasinghe \\ Solomon Islands National University, Honiara, Solomon Islands
}

Copyright $(2016$ by authors, all rights reserved. Authors agree that this article remains permanently open access under the terms of the Creative Commons Attribution License 4.0 International License

\begin{abstract}
For more than 50,000 years of Papua New Guinea's human history, Papua New Guineans have been making significant contributions to Science, particularly in the fields of Chemistry and Medicine. However, because of the absence of any written language for over 800 dialects, the information has not been recorded and the contributions of ancient Papua New Guineans have largely gone unnoticed and unrecognized. However, during the past 40 years, some researchers, Holdsworth[1], Woodley [2], Timi[3], Dindi [4], Rai[5] have conducted scientific studies on medicinal plants in PNG which probably would have been used by ancient Papua New Guineans to treat deceases. Identification of the plants were carried out with the help of villagers initially and then with botanists and chemists Papua New Guinea. Chemical characterization was carried out by chemists in Papua New Guinea. Nine years ago, the author was able to introduce a Unit in the Grade 11 and 12 Chemistry Syllabus under the title 'Traditional Chemical Practices' which consists of traditional chemical and medicinal activities. Similar units had been introduced at undergraduate level in the University of PNG 7 years ago. Already there is evidence that the learning of what their ancestors had discovered and used has been an inspiration to students, and can stress the importance of learning modern scientific principles and methods to build on what their forefathers had done. This paper summarizes some of the scientific contributions of ancient Papua New Guineans, and endeavours to show how the studying of them at school and university levels may have influenced students to join chemical and medical streams at universities and encouraging first year undergraduates to take up chemistry in later years.
\end{abstract}

Keywords Ethnochemistry, Ethnomedicine, Ancient Papua New Guineans, Motivating Students

\section{Introduction}

Papua New Guinea is characterized by geological, ethnic and biological diversity. It contains approximately $6 \%$ of the world's biodiversity in $1 \%$ of the worlds land area. This allowed people of this country to use its flora and other resources to produce what they wanted. Although not widely documented and appreciated, medicine and chemistry have been associated with Papua New Guineans for thousands of years. They also have been using indigenous plants for treatment of diseases for thousands of years. The first medicinal plants recorded in Papua New Guinea were shown to the Russian botanist and explorer Miklouho- Maclay who lived on Coast of now Madang Province from 1871 and 1876. Many other traditional plants used as medicines have been since recorded by missionaries, visiting botanists and anthropologists. Several research projects in traditional medicine are currently being conducted at the University of Papua New Guinea, Institute of Medical Research and Wau Ecology Institute of Papua New Guinea.

\section{Examples of Medicinal Uses of Plants by Ancient Papua New Guineans}

\section{(a) Aloe Vera L.}

Local Name: Aloe

Medicinal Uses: Used by ancient people as a treatment for stomach ulcers. Currently is also used to treat X-ray burns.

Chemistry: Aloe vera contains C-glycosylchromone and its aglycon aloesone which absorb ultraviolet light.

\section{(b) Alstonia scholaris (L.) R. Br.(Devils Tree)}

Local Names: Budo (Normanby Island), Herina (Central Province), Kambu (Sepik Province), Puto (Milne Bay Province), Sipuel ((Manus Island) and Watsi (East New Britain Province. 
Medicinal Uses: In Morobe Province, the dried bark is crushed and mixed with water and given to patients with malaria or stomach ache. Dysentery and diarrhoea are treated in Manus Island using leaves. In Milne Bay Province, tropical ulcers are treated by sap applied externally.

Chemistry: Contains alkaloids, alstonamine, ditamine, echitamine and echitenine

\section{(c) Barringtonia Asiatica (L.) Kurz (Sea Poison Tree)}

Local Names: Mbrut (Manus Province) and mwanumbu (Milne Bay Province)

Medicinal Uses: Sores are treated by scraped fresh nut. Powdered nut is mixed with water and given patients to drink to treat bronchitis and swollen spleen after malaria.

Chemistry: Bartogenicacid, 19-epibartogenic acid, anhydrobartogenic acid, hydrocyanic acid and monosacccharides.

(d) Euphorbia hirta L. Euphorbiaceae (Asthma weed and Cat's hair)

Local Names: Gigirogo (Central Province); Tantad, (East New Britain); Wilai (East Sepik Province).

Medicinal Uses: Used in the treatment of Asthma and internal haemorrhaging. Flowers of this plant are taken internally to cure infertility.

Chemistry: Spectral analysis reveals two compounds with molecular formulae of $\mathrm{C}_{31} \mathrm{H}_{50} \mathrm{O}$ and $\mathrm{C}_{30} \mathrm{H}_{50} \mathrm{O}$. The structures of the compounds were 24-methylenecycloartan-3-ol and 9(11)- fernen-3-ol respectively. Preliminary studies on these naturally occurring fernane-type and cycloartane-type have shown that they have anti-HIV activity.

(e) Euphorbia thymifolia (L.) (Spurge)

Local Names: Not available

Medicinal Uses: Sore eyes are treated by squeezing sap into eyes.

Chemistry: Contains Alkaloids, bixanin, casuarin, corilagin, 1-degalloyleugeniin, diterpenes, isomallotinic and pedunculagin.

(f) Flagellaria indica L.(Whip Vine, Supple Jack)

Local Names: Guiaiti (Sepik Province), Gwana (Central Province), Mingop (Morobe Province) and Vuvu (West New Britain Province)

Medicinal Uses: Roots are used as a contraceptive.

Chemistry: Contains flavonoids.

\section{Other Scientific Contributions}

The first inhabitants of Papua New Guinea had arrived at least 40,000 years ago, having travelled through the south-east Asian peninsula. These first inhabitants, from whom the Papuan people are probably descended, adapted to the range of ecologies and in time developed one of the earliest known agricultures. Remains of this agricultural system, in the form of ancient irrigation systems in the highlands of Papua New Guinea, are being studied by archaeologists. Sugar cane was cultivated for the first time in Papua New Guinea around 6000 B.C. Western agronomists still do not understand all practices, and it has been noted that native gardeners are as or more successful than most scientific farmers in raising certain crops. There is evidence that Papua New Guinea gardeners invented crop rotation well before western Europeans.

Papua New Guineans have been chewing betel nuts for tens of thousands of years. Lime is an essential ingredient of betelnut. They produced lime either using limestones or sea shells. Ancient Papua New Guinean knew that the decomposition of limestones was an endothermic reaction and therefore supplied heat to carry out the reaction. They soon discovered that the main product, calcium oxide was too corrosive to eat directly with betelnut and mustard because the reaction of $\mathrm{CaO}$ with saliva in the mouth was an exothermic and a corrosive one. Therefore, they carried out the reaction by adding water to calcium oxide in a vat and took the final product $\mathrm{Ca}(\mathrm{OH})_{2}$ after allowing it to cool.

Ancient Papua New Guineans have been also known for their salt making skills. Those who were living near sea produced salt by solar evaporation of sea water. Traditional dye making has been a common practice throughout PNG. Most traditional dyes in PNG come from plant sources. Dyes are normally used for painting on traditional costumes and even on human bodies for decoration purposes during special occasions. The methods of preparation and plant species vary. The Mian people of Gumini and the Warea's of Morobe Province amazingly use the same tubers of a native plant for dye making. These plants are grown mostly in old cemeteries and abandoned villages. The tubers are removed, washed properly and are scraped into pieces. The scrapings are rubbed against traditional woven ropes and other traditional costumes. This gives a bright yellowish colour. From the same tuber the Warea people add lime to the scrapings and make red dye (at higher $\mathrm{pH}$ ).

Not much information is available on the production of alcohol from traditional raw materials. Gumini is one of the very few places in PNG where beer is still traditionally brewed. The Gumini people make their beer from mushrooms. These are very special mushrooms. The mushrooms are picked and boiled as food. It normally takes half a day to cook the soft mushrooms. When it is properly cooked then the mushroom can be served. It is thought that the presence of some enzymes carbohydrate is converted to alcohol.

\section{How Studying Ethnochemistry and Ethnomedicine has encouraged School Student and Undergraduates to take up Chemistry}

10 years ago, the student numbers in Grade 12 chemistry has been similar to those of other science courses such as 
physics and biology. Since ethnochemistry and ethnomedicine were introduced 3 years ago in Grade 11 and 12, [Marasinghe 6], chemistry has been becoming one of the most popular subjects among the students at upper secondary level. In fact only English language and general mathematics which are compulsory for every student had more number of students. Table 1 shows number of students sat for each subject in 2012 Grade 12 examinations

Table 1. Students numbers in 2012 Grade 12 Examination in PNG

\begin{tabular}{|c|c|c|}
\hline No & Subject & No of Students \\
\hline 1 & *English & 10870 \\
\hline 2 & * General Mathematics & 9279 \\
\hline $\mathbf{3}$ & Chemistry & $\mathbf{6 0 6 7}$ \\
\hline 4 & *Advanced Mathematics & 5363 \\
\hline 5 & Geography & 4754 \\
\hline 6 & History & 4515 \\
\hline 7 & Biology & 3907 \\
\hline 8 & Business Studies & 3748 \\
\hline 9 & Physics & 3287 \\
\hline 10 & Accounting & 2709 \\
\hline 11 & Information Technology & 1329 \\
\hline 12 & Legal Studies & 1120 \\
\hline
\end{tabular}

*Compulsory subjects. Every Student must take up either general or advanced mathematics

Table 2. Number and percentage of 2nd year students in the Dept. of Chemistry, University of Papua New Guinea.

\begin{tabular}{|c|c|c|c|}
\hline Year & $\begin{array}{c}\text { No of students } \\
\text { in the } 1^{\text {st }} \text { year in } \\
\text { the previous } \\
\text { year }\end{array}$ & $\begin{array}{c}\text { No of students } \\
\text { opting to study } \\
\text { chemistry in the } \\
2^{\text {nd }} \text { year }\end{array}$ & $\begin{array}{c}\% \text { of students from } \\
1^{\text {st }} \text { year (foundation } \\
\text { year) Opting for } \\
\text { chemistry in the } 2^{\text {nd }} \\
\text { year }\end{array}$ \\
\hline 2004 & 350 & 40 & 11.4 \\
\hline 2005 & 375 & 53 & 14.1 \\
\hline 2006 & 400 & 89 & 22.3 \\
\hline 2007 & 430 & 102 & 23.7 \\
\hline 2008 & 475 & 126 & 26.5 \\
\hline 2009 & 500 & 186 & 37.2 \\
\hline 2010 & 500 & 239 & 47.8 \\
\hline
\end{tabular}

Similar to the case of school students, undergraduates too are inspired by the study of traditional chemistry. After completing first year (Foundation Science) course at the University of PNG (UPNG) about 80 students are selected to enter the School of Medical and Health Sciences to follow courses such as medicine, nursing and dentistry etc. The remainder can choose any of the six departments (Biology, Chemistry, Earth Sciences, Environmental and Geography, Mathematics and Physics). Units of ethnochemistry and ethnomedicine were introduced to the first year (Foundation
Year) course in 2005. In the School of Natural and Physical Sciences out of 500 students, on average each department can expect about 70 students. In 2005, about 53 students opted to follow Chemistry courses from second year onwards. However, in 2010, the number of students in the second year Chemistry was 239 which were more than 3 times the average.

\section{Discussion and Conclusions}

Ancient Papua New Guineans have made a significant contribution to Science, particularly in Medicine and Chemistry. This paper covers only a small proportion of the immense knowledge of traditional medicine, the plant species from which they are derived, the diseases they can treat and the parts of the plants to be used. As shown in Table 1, by 2012, the student numbers in Grade 12 Chemistry were far higher than those in other non-compulsory subjects and the numbers and the percentages of students opting to study Chemistry in the second year at the University of PNG have been steadily rising from 2004 to 2010 .

The author does not attribute this increase in student numbers in Chemistry courses entirely to the introduction of ethnochemistry at school and undergraduate levels. There may have been other factors. However, the increase in the percentage of students deciding to study Chemistry at Grade 12 and beyond has been remarkable and probably has its basis at least to some extent in students receiving a taste of the chemistry and medicine carried out by their ancestors.

\section{REFERENCES}

[1] Holdsworth, D.K. 'Medicinal Plants of Papua New Guinea' In: Folk Medicine - The Art and the Science. Edited by Richard P. Steiner Pub: American Chemical Society, 1986.

[2] Woodley E. 'Medicinal Plants of PNG. Part 1: Morobe Province. Wau Ecology Institute Handbook No 11, Wau, PNG 1991.

[3] Timi D. 'Medicinal Plant Survey of Papua New Guinea'. In: Science of Pacific Island Peoples. Ed John Morrison, Paul Geraghty and Linda Crowl. Pub: Institute of Pacific Studies, Fiji 1994.

[4] Dindi, M., Bugani, T., Ireland, C., Harper, M.K. and Matainaho, T., Isolation of Bioactive Compounds from Papua New Guinea Plant Euphorbia Cf. Hirta' In: Journal of Institute of Chemists, PNG vol 1. No 12008.

[5] Rai P. 'Medicinal Plants in Papua New Guinea'. Pub: World Health Organization 2009.

[6] Marasinghe, B. 'Upper Secondary Chemistry' - A textbook of Chemistry. Pub: University of UPNG Press March 2010. 